timationsprobleme stellt. Gerade bei dem Konflikt im Nahen Osten stellt sich die Frage, ob ein Befassen des IStGH sinnvoll ist oder ob es nicht zweckdienlicher wäre, zunächst eine politische Lösung zu finden und Völkerrechtsbrüche abzustellen, bevor mögliche Strafverfolgungsmaßnahmen ergriffen werden. Befasst sich der IStGH weit vor einer - im Falle Israels/ Palästinas unabsehbaren - politischen Lösung des Konflikts mit Fragen der strafrechtlichen Ahndung, könnte er sich politisch instrumentalisieren lassen. ${ }^{58}$ Diese Gründe haben unter

58 Vgl. auch Ronen, a.a.O. (Fn. 17), S. 3 ff. (S. 24 f., 27). anderem die deutsche Bundesregierung bewogen, sich bei der Abstimmung zur Verleihung des Status als Beobachterstaat in New York zu enthalten. ${ }^{59} \mathrm{Ob}$ diese Zweifel berechtigt sind oder ob ein mögliches Tätigwerden des IStGH im Nahostkonflikt einer Lösung neuen Antrieb verleihen wird, hängt nicht zuletzt von der Tätigkeit des IStGH ab und bleibt daher abzuwarten.

59 Vgl. Pressekonferenz der Bundeskanzlerin am 6. Dezember 2012, http://www.bundesregierung.de/Content/DE/Mitschrift/ Pressekonferenzen/2012/12/2012-12-06-merkel-netanjahu.html.

\title{
The Role of National Investigations in the System of International Criminal Justice - Developments in Germany
}

\author{
Andreas Schüller*
}

\begin{abstract}
With the adoption of the Rome Statute in 1998, a new system of international criminal justice has been created. The preamble of the Rome Statute emphasizes the mutual interest of the international community as a whole to prosecute international crimes as well as to cooperate with the International Criminal Court (ICC). Thus, there is a burden-sharing envisaged within the international criminal justice system, in which national prosecution services complement the work of the Office of the Prosecutor of the ICC. This article presents the history and evaluates the changes within the practice of the German Federal Public Prosecutor in the prosecution of international crimes. Further it focusses on perspectives and chances considering the cooperation of national prosecutors with the ICC in prosecuting powerful actors contrary to a states' foreign policy.
\end{abstract}

Keywords: Code of Crimes against International Law, Federal Prosecutor General, international crimes, complementarity, International Criminal Court, universal jurisdiction

Völkerstrafgesetzbuch, Generalbundesanwalt, Völkerstraftaten, Komplementarität, Internationaler Strafgerichtshof, Weltrechtsprinzip

\section{Introduction}

$\mathrm{T}$ The adoption of the Rome Statute of the International Criminal Court (ICC Statute) in 1998 and its ratification by states put pressure on the latter to revisit their national laws regarding the prosecution of international crimes. ${ }^{1}$ With the ICC Statute, a first international treaty was created that criminalizes a large number of acts, most of them already prohibited under customary international law, ${ }^{2}$ and that introduced a new system of international criminal justice. This new system has the International Criminal Court (ICC) as a last resort, since the ICC Statute emphasizes that it is the primary responsibility of the states to prosecute international crimes. Not only the proximity to the evidence, but also the

* LL.M. (adv.) - Legal Advisor, International Crimes and Accountability Program, European Center for Constitutional and Human Rights e.V. (ECCHR), Berlin - www.ecchr.eu; E-Mail: schueller@ecchr.eu.

This article has successfully undergone a double-blind peer-review process. The author would like to thank Wolfgang Kaleck, Aaaelen Micus and the unknown reviewers of the $\mathrm{S}+\mathrm{F}$ journal for theier comments on earlier drafts of this article.

1 See e.g., Amnesty International, Universal jurisdiction: A preliminary survey of legislation around the world - 2012 update, Index: IOR 53/019/2012, Amnesty International, October 2012.

2 On international crimes as violations of customary international law, see G. Werle, Principles of International Criminal Law (2005), pp. 49-50, and A. Cassese, International Criminal Law (2008), pp. 11-13. impact and meaning of trials close to the crime scene and within the society in which victims and perpetrators live, stand for the importance of prosecutions in the territorial state. Trials in a third state or before an international court such as the ICC are a last resort, taking into account security or infrastructural problems, but also political interferences in the territorial state. However, not only the technical legal implementation of the ICC Statute on national level faces challenges, but also the political considerations, when the investigations of a state's law enforcement authorities go against a state's foreign policy. As a result of the latter challenge, only perpetrators of international crimes from very few states have been prosecuted so far before third states' courts, e.g. those from former Yugoslavia or Rwanda. ${ }^{3}$ The ICC's complementarity principle enshrined in article 17 of the ICC Statute requires the states' inability or unwillingness as admissibility test to prosecute the crimes before the ICC. This new system reverses the ad hoc tribunals' concept, in which primary responsibility for the prosecution of crimes committed in former Yugoslavia and in Rwanda lay with the respective tribunal. ${ }^{4}$ The new system of

3 See especially M. Langer, The Diplomacy of Universal Jurisdiction, 105 Am. J. Int'l L. 2011, pp. 1-49.

4 On the primacy of these tribunals over national courts, see A. Cassese, International Criminal Law (2008), pp. 339-342. 
international criminal law has another component besides the complementarity principle: states have an obligation to cooperate with the ICC. ${ }^{5}$ Member states are not only obliged to prosecute crimes themselves, ${ }^{6}$ but also to act in mutual assistance of the Court's work. The complementarity principle and the duty to cooperate in cases of international crimes, in which evidence is typically spread all over the world, emphasizes the world community's burden of contributing to the investigation and prosecution of international crimes.

Germany introduced its Code of Crimes against International Law (CCIL) in 2002 to be able to prosecute all crimes established under the ICC Statute at the domestic level. ${ }^{7}$ Prior to 2002, international crimes were punishable under ordinary German criminal law. Thus, the CCIL presented a new development for German law enforcement agencies, but no new start in itself. On the other hand, Germany saw its international obligations fulfilled with the adoption of the CCIL, without seriously expecting to enforce the law and not envisaging situations such as those described below, in which the CCIL actually would apply.

\section{Development from the 1990s to Today}

\subsection{Prosecution of International Crimes in the 1990s: First Experiences}

With the introduction of the new CCIL, German law enforcement authorities did not start from zero. The Federal Criminal Police and the Federal Public Prosecutor's Office had already gained experience in transnational investigations of international crimes and cooperation with international tribunals in the 1990s when German authorities investigated and prosecuted international crimes committed in former Yugoslavia. ${ }^{8}$ At the time, Germany investigated 127 cases involving 177 suspects regarding genocide and grave breaches of the Geneva Conventions. ${ }^{9}$ These prosecutions were in line

5 Article 86 of the ICC Statute, which reads: "States Parties shall, in accordance with the provisions of this Statute, cooperate fully with the Court in its investigation and prosecution of crimes within the jurisdiction of the Court."

6 The obligation of states to investigate and prosecute exists in a number of international treaties such as the Geneva Conventions, the Convention against Torture and Other Cruel, Inhuman or Degrading Treatment or Punishment or the International Convention for the Protection of All Persons from Enforced Disappearance.

7 See G. Werle, Völkerstrafrecht und das deutsche Völkerstrafgesetzbuch, JZ 2012, 373-380 (374). There are some differences between the CCIL and the Rome Statute, one major distinction being the almost equal application of crimes to international and non-international armed conflicts.

8 W. Kaleck, German International Criminal Law in Practice: From Leipzig to Karlsruhe, in: Kaleck/ Ratner/ Singelnstein/ Weiss (eds.), International Prosecution of Human Rights Crimes (2007), 93-112 (98-100).

9121 investigations were closed, one transferred to the ICTY (Duško Tadić, see Investigation Judge at the Federal Supreme Court (Arrest Warrant), case file no. 1 BGs 100/94) and five prosecuted (N. Djajić, see Bavarian Higher Regional Court, judgment of 23 May 1997, case file no. 3 St 20/96; N. Jorgić, see Higher Regional Court Duesseldorf, judgment of 26 September 1997; Federal Supreme Court, judgment of 30 April 1999, Case file no. 3 StR 215/98; for an English summary see the ECtHR judgment of 12 July 2007 in this case, ECtHR case no. 74613/01; M. Sokolović, see Higher Regional Court Duesseldorf, judgment of 29 November 1999; Federal Supreme Court, judgment of 21 February 2001, Case file no. 3 StR 372/00; Đ. Kušljić, see Bavarian Higher Regional Court, judgment of 15 December 1999, case file no. 6 St 1/99; Federal Supreme Court, judgment of 21 February 2001, case file no. 3 StR 244/00), see R. Hannich, Justice in the Name of All, ZIS 13/2007, 507-514 (510). with German foreign policy at the time, supporting the creation of the very first United Nations ad hoc tribunal in The Hague and later participating in the NATO campaign in Kosovo. In cases regarding the military dictatorships in Argentina and Chile, prosecutions could not be based on counts of international crimes, but on a number of provisions of ordinary German Criminal Law, because crimes against humanity are not punishable when committed before 30 June 2002, the date of entry into force of the CCIL. ${ }^{10}$ However, the use of ordinary criminal law caused a number of procedural and other problems, such as the limited jurisdiction (basically only cases of German nationals as victims could be considered), shorter statutory periods of limitations and a lesser range of modes of liability as under international criminal law. ${ }^{11}$ However, particularly remarkable are the arrest warrants issued by the local Nuremberg court against the Argentinean ex-military junta leaders Jorge Rafael Videla and Eduardo Emilio Massera in 2003. In the following years, Argentina denied their extradition to Germany and instead prosecuted both before domestic courts. ${ }^{12}$

\subsection{The First Five Years of the CCIL, 2002-2007: Standstill}

The CCIL entered into force on 30 June 2002, parallel to the establishment of the International Criminal Court on 1 July 2002.13 At the same time, the German Code of Criminal Procedure was amended and a provision on prosecutorial discretion, about whether to initiate an investigation or not regarding allegations of international crimes, was introduced in article $153 \mathrm{f} .{ }^{14}$ The CCIL was subsequently translated into eight languages in order to serve as a role model. ${ }^{15}$ However, German authorities considered their obligations fulfilled by these measures, without expecting any situation of practical relevance to apply the law to. As a consequence, within the German Federal Prosecutor's Office, the competent authority to investigate crimes under the CCIL, three Federal Public Prosecutors of the department for international terrorism were, in addition to the latter crimes, assigned to the section of international crimes. ${ }^{16}$ The lack of resources within the Federal Public Prosecutor's Office, as well as a number of heavily criticized decisions not to open investigations, led to an expert hearing in the Committee on Human Rights and Humanitarian Aid of the German Parliament on the

10 Also note that Germany explicitly upheld a reservation to article $7 \S 2$ of the Eur. Conv. on H.R., which permits the retroactive national prosecution of crimes against humanity as a crime under international law, until 2001. The reservation reflects the opposing policy in Germany towards international crimes, stemming from the prosecution of Nazi-crimes, which was never a priority on Germany's agenda; see G. Werle, Völkerstrafrecht und das deutsche Völkerstrafgesetzbuch, JZ 2012, 373-380 (374).

11 W. Kaleck, German International Criminal Law in Practice: From Leipzig to Karlsruhe, in: Kaleck/ Ratner/ Singelnstein/ Weiss (eds.), International Prosecution of Human Rights Crimes (2007), 93-112 (100-102).

12 See for more information about the prosecutions of Argentinean military dictatorship crimes W. Kaleck, Kampf gegen Straflosigkeit - Argentinien Militärs vor Gericht (2010).

13 Federal Law Gazette, Vol. I, p. 2254; see also G. Werle, Völkerstrafrecht und das deutsche Völkerstrafgesetzbuch, JZ 2012, 373-380 (375-377).

14 The English text is available at: www.gesetze-im-internet.de/englisch_stpo/.

15 The translations of the CCIL are available at the Max Planck Institute for Foreign and International Criminal Law, under www.mpicc.de/ww/de/pub/ forschung/publikationen/onlinepub.htm.

16 German Parliament, Response by the Government, 16/4267, 5 February 2007, Q. 1 and 2 . 
occasion of the CCIL's fifth anniversary in 2007, marking a first evaluation after five years and consequently a turning point in German policy. ${ }^{17}$

The first decisions on international crimes committed abroad after 2002 dealt primarily with immunity issues and were widely criticized for interpreting international law too broadly in order to refrain from the obligation to initiate an investigation. ${ }^{18}$ The first significant criminal complaint submitted under the new CCIL in 2004 concerned torture in the US-detention center of Abu Ghraib in Iraq. ${ }^{19}$ The Federal Public Prosecutor - in exercising its discretion - refused to open an investigation, applying article $153 \mathrm{f}$ of the German Code of Criminal Procedure and arguing that the crimes were already under investigation in the USA and that thus a German proceeding would be subsidiary. ${ }^{20}$ The timing of the Prosecutor's decision, two days before one of the named suspects, Donald Rumsfeld, was supposed to speak at the Munich Security Conference, led to a reprehension of Germany by the UN Special Rapporteur on the Independence of the Judiciary. ${ }^{21}$ Likewise, experts in the parliament's hearing in 2007 criticized the assumption that German law would be subsidiary in case another state or international court conducts investigation into the same "situation". Only when investigating the exact same case, subsidiarity may be argued, according to the experts. ${ }^{22}$ Another potentially significant shortcoming of the German system of prosecuting international crimes was seen by the experts in the status of the Federal Public Prosecutor as a "political magistrate" who has to follow the directives of the Minister of Justice in discretional decisions based on article $153 \mathrm{f} \mathrm{StPO}$ regarding the initiation of investigations and the lack of the possibility of a full judicial review of the discretional decision. ${ }^{23}$

In 2005, a further important step regarding the prosecution of international crimes was undertaken. The Minister of Interior

17 German Parliament, Committee on Human Rights and Humanitarian Aid, 16th period, The national implementation of the Code of Crimes against International Law, 24 October 2007, Public expert hearing, available at: http://webarchiv.bundestag.de/cgi/show.php?fileToLoad=1366\&id=1136 (in German).

18 Relevant cases were those on China regarding Falun Gong (Federal Public Prosecutor, Decision on Closing of Investigations, 24 June 2005, case file no. 3 ARP 654/03-2) as well as on Russia/Chechnya (Federal Public Prosecutor, 28 April 2005, case file no. 3 ARP 35/05-2). See statements by C. Kress, p. 9 and 10, and K. Ambos, p. 4, in: German Parliament, Committee on Human Rights and Humanitarian Aid, 16th period, The national implementation of the Code of Crimes against International Law, 24 October 2007, Public expert hearing, available at: http://webarchiv.bundestag.de/cgi/show. php?fileToLoad=1366\&id=1136 (in German); see also W. Kaleck, German International Criminal Law in Practice: From Leipzig to Karlsruhe, in: Kaleck/ Ratner/ Singelnstein/ Weiss (eds.), International Prosecution of Human Rights Crimes (2007), 93-112 (106-108); N. Geissler/ F. Selbmann, Fünf Jahre Völkerstrafgesetzbuch - eine kritische Bilanz, HuV-I 3/2007, 160-166 (164).

19 See the complaint and a number of additional documents at the website of the European Center for Constitutional and Human Rights, www.ecchr. eu, www.ecchr.de/index.php/us_accountability/articles/complaint-againstformer-us-secretary-of-defense-donald-rumsfeld.html; W. Kaleck, German International Criminal Law in Practice: From Leipzig to Karlsruhe, in: Kaleck/ Ratner/ Singelnstein/ Weiss (eds.), International Prosecution of Human Rights Crimes (2007), 93-112 (103-106).

20 See ibid.

21 United Nations, General Assembly, Human Rights Council, 4th session, Report of the Special Rapporteur on the independence of judges and lawyers, Leandro Despouy, A/HRC/4/25/Add.1, 5 April 2007, paras.154-160, available at www.ecchr.de/index.php/us-folterfaelle/articles/rumsfeld. html?file=tl_files/Dokumente/Universelle\%20Justiz/Bericht\%20UNSonderberichterstatter.pdf.

22 See statements by C. Kress, p. 11; K. Ambos, p. 3, available at link supra note 18.

23 See statements by C. Kress, p. 16; W. Kaleck, p. 2; K. Ambos, p. 4, available at link supra note 18. of Uzbekistan, Zakirjan Almatov, allegedly one of the most responsible for the Andijan massacre ${ }^{24}$ in which hundreds of protesters were killed by Uzbek security forces, stayed in Germany for medical treatment, despite an EU-wide travel sanction against him and others. ${ }^{25}$ A criminal complaint filed against Almatov ${ }^{26}$ was dismissed by the Federal Public Prosecutor, who stated that his office only became aware of Almatov's presence in Germany through the criminal complaint and thus did not have sufficient time to gather evidence that would stand before the Federal Supreme Court in requesting an arrest warrant. ${ }^{27}$ The decision by the German government to grant Almatov a visa based on humanitarian grounds despite the travel ban, as well as the alleged lack of knowledge of the Federal Public Prosecutor about Almatov's presence in Germany and the refusal to examine the available evidence led to massive criticism regarding the enforcement of the CCIL by German authorities. ${ }^{28}$

A year later, in November 2006, a second criminal complaint was filed regarding torture in Abu Ghraib and the detention facility at Guantanamo Bay, arguing that there are still no effective criminal investigations in the USA and thus challenging the argumentation of the Federal Public Prosecutor in its dismissive decision of 2005. ${ }^{29}$ However, the Federal Public Prosecutor again denied the initiation of a criminal investigation. ${ }^{30}$ This time, the Prosecutor argued that it was very unlikely that one of the suspects named in the complaint would ever travel to Germany, in order for arrests and prosecutions to become realistic. Suggestions that the prosecutor investigates to secure evidence, with no commitment to a prosecution, were dismissed. Experts at the 2007 parliament's hearing requested activities by German law enforcement authorities with regard to securing evidence whenever possible in order to cooperate and facilitate investigations by other prosecutorial authorities, such as the ICC, and thus to implement the concept of so-called "anticipatory mutual legal assistance" 31.32

24 See, e.g., Human Rights Watch, „Bullets Were Falling Like Rain“, Report, 7 June 2005

25 Council of the European Union, Common Position 2005/792/CFSP concerning restrictive measures against Uzbekistan, 14 November 2005, Official Journal of the European Union, L 299/72.

26 See the complaint at the website of the European Center for Constitutional and Human Rights, www.ecchr.eu, www.ecchr.de/index.php/almatov_case. html; see also W. Kaleck, German International Criminal Law in Practice: From Leipzig to Karlsruhe, in: Kaleck/ Ratner/ Singelnstein/ Weiss (eds.), International Prosecution of Human Rights Crimes (2007), 93-112 (109110).

27 See ibid.

28 See statements by C. Kress, p. 16; K. Ambos, p. 5, available at link supra note 18. S. Zappalà, The German Federal Prosecutor's Decision not to Prosecute a Former Uzbek Minister - Missed Opportunity or Prosecutorial Wisdom?, J Int Criminal Justice (2006) 4 (3): 602-622; Amnesty International and Human Rights Watch, Open Letter to German Federal Minister of Justice, 8 May 2006, available at http://www.ecchr.de/index.php/almatov_case. html?file=tl files/Dokumente/Universelle\%20Justiz/Almatow\%2C\%20 Offener\%20Brief\%20ai-hrw\%2C\%202006-05-08.pdf.

29 See the complaint and a number of additional documents at the website of the European Center for Constitutional and Human Rights, www.ecchr. eu, www.ecchr.de/index.php/us_accountability/articles/complaint-againstformer-us-secretary-of-defense-donald-rumsfeld html; see also K. Gallagher, Universal Jurisdiction in Practice - Efforts to Hold Donald Rumsfeld and Other High-level United States Officials Accountable for Torture, J Int Criminal Justice (2009) 7 (5): 1087-1116.

30 See ibid.

31 See for a further explanation 3.1

32 See statements by W. Kaleck, p. 3-5; H.-P. Kaul, p. 2; C. Kress, p. 8-9 and 12, available at link supra note 18 . 


\subsection{The Years Five to Ten, 2007-2012: Changes and Developments}

In 2009, a new department was established in the Federal Public Prosecutor's Office to prosecute international crimes; however, the number of prosecutors often changes. ${ }^{33}$ In addition, the Federal Criminal Police installed the "Central Unit for the Fight against War Crimes and further Offences pursuant to the Code of Crimes against International Law" (ZBKV for its German initials), often referred to as "war crimes unit", with up to five investigators and five analysts. ${ }^{34}$ In total, the Federal Public Prosecutor opened 29 investigations against 56 suspects as well as three structural investigations until November 2012. ${ }^{35}$ Twelve investigations have already been closed, among them nine against suspects from the German armed forces as well as one against a Taliban member from Afghanistan. ${ }^{36}$ A number of other criminal complaints filed with the Federal Public Prosecutor did not lead to criminal investigations because they could not prove a first suspicion that a crime under the CCIL had been committed, temporal jurisdiction did not exist or immunities hindered investigations. ${ }^{37}$

Investigations on the Rwandan genocide were initiated, ending in an indictment against Onesphore Rwabukombe before the Higher Regional Court in Frankfurt in 2010.38 Further investigations, which had previously been stopped in 2006 and 2007, were reinitiated regarding crimes committed by the Rwandan rebel group "Forces Démocratiques de Libération du Rwanda"(FDLR) in the eastern part of the Democratic Republic of the Congo (DRC), leading to trials against their leaders Ignace Murwanashyaka and Straton Musoni in 2010. ${ }^{39}$ In cooperation with the ICC, the Federal Public Prosecutor exchanged evidence regarding the FDLR, which is also under investigation by the ICC. ${ }^{40}$ Both German prosecutions have been welcomed by the concerned states, and the Republic of Rwanda permitted and facilitated investigations inside the country through German investigation teams. At the same

33 The Federal Government stated the number of nine prosecutors in autumn 2012 (German Parliament, Response by the Government, 17/11339, 7 November 2012, Q. 4); however, in spring 2013 the number decreased to only 4.5 positions according to the Federal Public Prosecutor's Office.

34 German Parliament, Response by the Government, 17/11339, 7 November 2012, Q. 4; the new Central Unit replaced the 2003 established Central Unit for the Fight against War Crimes and forms part of the department of state security (Referat ST24, Abteilung Polizeilicher Staatsschutz) within the Federal Criminal Police.

35 German Parliament, Response by the Government, 17/11339, 7 November 2012, Q. 1. For the term „structural investigations" see 3.1.

36 German Parliament, Response by the Government, 17/11339, 7 November 2012, Q. 2.

37 Regarding immunities, see, e.g. the case of Uzbek head of secret service Rustam Inoyatov as well as Afghan warlord Rashid Dostum, who both enjoyed immunity because they entered Germany on official invitation of the government and the case of Sri Lankan Major General Jagath Dias, who enjoyed diplomatic immunity because he was accepted by the German government as vice ambassador for Sri Lanka. However, he had to withdraw from his post after public pressure forced the German government to find a solution with Sri Lanka, see www.ecchr.de/index.php/sri-lanka.404/articles/ the-jagath-dias-case.html.

38 Higher Regional Court Frankfurt, case file no. 5 - 3 StE 4/10 - 4 - 3/10. Please note that the charges were brought for genocide under the old article 220a of the ordinary Criminal Code, in force in 1994, not the new CCIL.

39 Higher Regional Court Stuttgart, case file no. 5- 3 StE 6/10.

40 International Criminal Court, The Prosecutor v. Callixte Mbarushimana, case file no. ICC-01/04-01/10; The Prosecutor v. Sylvestre Mudacumura, case file no. ICC-01/04-01/12. Please note, the Pre-Trial Chamber I declined to confirm the charges on 16 Dec. 2011 and the suspects has been released from the Court's custody. time, the investigations required a major part of the resources of the departments in the Federal Public Prosecutor's Office as well as the Federal Criminal Police.

In September 2009, a new challenging case entered the Federal Public Prosecutor's Office: the aerial attack ordered by a German Colonel on a large group of persons gathering at two fuel tankers near Kunduz, Afghanistan, on 4 September 2009. Both tankers had been kidnapped by insurgents, but then got stuck at a sandbank when trying to cross the Kunduz river. Most insurgents left and the local population took the opportunity to provide themselves with fuel. After hours of air surveillance, the attack was ordered, killing about 100 persons. ${ }^{41}$ Based on an examination of written documents and reports of mainly military institutions as well as on the testimonies given by the two suspects and two of their colleagues present during the decision-making process to target the crowd, the Federal Public Prosecutor decided within a month, that no crime under the CCIL had been committed and closed the case. ${ }^{42}$ Independent investigative steps, separated from the military, beyond questioning the suspects and their colleagues, did not take place. The legality of this decision as well as whether the investigations met the standards set by the European Court of Human Rights regarding effectiveness, is currently pending before the German Federal Constitutional Court. ${ }^{43}$

In 2011, the Federal Prosecutor took testimonies of witnesses in Germany regarding international crimes committed in Libya. The formal investigation was not directed against a named individual, but focused on evidence accessible in Germany. In this way, Germany assisted the ICC investigations on the situation of Libya. ${ }^{44}$ And, although the situation in Syria is currently not under the jurisdiction of the ICC, the Federal Public Prosecutor began gathering testimonies of witnesses present in Germany. ${ }^{45}$ Similar practices have been applied to one other country. 46

\section{Challenges and Perspectives for Prosecutions of International Crimes}

\subsection{Perspectives in Structural Investigations ${ }^{47}$}

"Structural investigations", representing the current status quo in Germany, are a very welcomed step in order to secure evidence in a procedure that is called "anticipated mutual legal

41 No official numbers exist, the German armed forces paid ex gratia reparation for 102 killed persons, see Ministry of Defense, "Bundeswehr zahlt Unterstützung für Familien der Opfer des Luftangriffs vom 4 September 2009", Website, 10 August 2010.

42 Federal Public Prosecutor, Decision on Closing of Investigations, 16 April 2010, case file no. 3 BJs 6/10-4; for a critical evaluation see W. Kaleck/ A. Schueller/ D. Steiger, Tarnen und Täuschen - die deutschen Strafverfolgungsbehörden und der Fall des Luftangriffs bei Kundus, Kritische Justiz, Vol. 3, 2010, pp. 270-286.

43 Federal Constitutional Court, case file no. 2 BvR 987/11.

44 International Criminal Court, Situation in Libya, ICC-01/11.

45 Federal Public Prosecutor, 3 BJs 38/11-4.

46 German Parliament, Response by the Government, 17/11339, 7 November 2012, Q. 1.

47 „Structural investigations“ are proceedings against unknown perpetrators. They also exist in situations, in which a formal investigation against an individual has been opened, in order to secure background information about the overall situation, see German Parliament, Response by the Government, 17/11339, 7 November 2012, Q. 7. 
assistance in criminal matters". It is deemed "anticipated", because the gathering of evidence takes place before there is an official request for legal assistance by the ICC or eventually another state. The aim is to secure the evidence available under the jurisdiction of the state in order to facilitate future proceedings in that same state, in a third state or before an international court. The recent opening of investigations on Libya and Syria are in line with current German foreign policy, which supported the ICC referral of the situation in Libya and advocates for the same step regarding Syria. ${ }^{48}$ The structural investigation of the Federal Public Prosecutor is a step in the right direction, since it fulfills the obligation of Germany within the system of international criminal justice to gather accessible evidence of international crimes. At the same time, it puts Germany in a position to react actively in case a suspect travels to Germany. Furthermore, the formal structural investigation in not focusing on single incidents or named suspects avoids strong political reactions and interference by states whose elite might be under investigation and thus enables the authorities to investigate more powerful actors at a preliminary level without directly entering political turmoil. Which conflict situations, countries and groups of perpetrators will be subject to such an investigation remains to be seen. Nevertheless, this approach can serve as an example for other European states on how to deal with the investigation and prosecution of international crimes, especially regarding potential political disputes.

\subsection{Judicial Review of Prosecutorial Discretion}

In order to achieve effective investigations in cases that might be controversial with regard to foreign policy, a full reexamination of the exercise of the prosecutorial discretion by a court is necessary. In case the Federal Public Prosecutor refuses to open an investigation, delays or closes an investigation, victims have only very limited chances to appeal that decision. Against decisions by the Federal Public Prosecutor, there is the possibility to request the reopening of the investigations through a court. ${ }^{49}$ However, this request has very high procedural burdens and the victim has to present his or her own evidence within four weeks. This is basically impossible, given the transnational character of the proceedings, problems in accessing the crime scene, language barriers, and often limited access to the file of the investigation. Thus, the effectiveness and seriousness of investigations undertaken by the Federal Public Prosecutor, as well as its legal interpretation of the CCIL, remains in most cases without any independent judicial review. Such a full judicial review would also lay aside any doubts regarding the independence of the Federal Public Prosecutor as a "political magistrate". The Federal Public Prosecutor forms part of the executive, not the judiciary, and has, according to civil service law, to act in fulfilling his or her tasks in continuous compliance with the relevant basic criminal policy aspects and goals of the government. ${ }^{50}$ This positi-

48 Germany voted in favor of the UN Security Council Resolution 1970 (2011), referring the situation of Libya to the ICC, 26 February 2011; Germany cosigned a letter by Switzerland to the President of the UN Security Council, asking for a referral of the situation in Syria to the ICC, 14 January 2013.

49 See article 172 of the German Code of Criminal Procedure.

50 See Website of the Federal Public Prosecutor, www.generalbundesanwalt. de/de/stellung.php. on requires the implementation of a full judicial review in order to balance the powers of the executive and the judiciary and to avoid politically motivated decisions in violation of the law or flawed legal interpretations. Only an independent judicial review can contribute to a less politically motivated selection of investigations. Without such a review, the danger, or at least the public assumption, persists that prosecutorial discretional decisions are based on general criminal policy and/or foreign policy considerations by the Federal Government and not on the independent and equal application of the law regardless of the position of a potential suspect.

\subsection{Capacities of German Law Enforcement Authorities}

Limited capacities are another obstacle in structural investigations and in focusing such investigations on high-level individual suspects. The adoption of the CCIL in 2002 was not accompanied by an adequate increase in the number of personnel and equipment for the competent authorities. This shortcoming is seen as having influenced the willingness of the Federal Public Prosecutor and its decisions not to initiate investigations and, although being competent, not to secure available evidence. No relevant capacity-consuming investigation was opened in the first years. From 2009, serious investigations outside Germany were conducted in the 1994 Rwandan genocide case and the FDLR-complex concerning the Eastern DRC following the positive decision by the Rwandan government to permit access of German officials to Rwanda. Still, these two on-going trials continue to bind major parts of the capacities of the relevant authorities. In relation to eleven other FDLR-supporters in Germany, investigations are on-going and three arrest warrants have led to arrests and indictments on terrorism-related charges, but not on international crimes, binding additional resources of the Federal Public Prosecutor. ${ }^{51}$ In addition, the Federal Criminal Police coordinates a special investigation unit regarding the FDLR. ${ }^{52}$ Current structural investigations into the situations of, e.g., Libya and Syria will remain superfluous as long as additional capacities are not being requested and assigned. Further, the continuity in the personnel of the Federal Public Prosecutor's Office is important to the often complex and long-lasting investigations and prosecutions, since often local prosecutors are only assigned for a period of two years to the relevant unit. Following these widely appreciated initiations of structural investigations, the question of how, with the current number of personnel, evidence can be gathered, mutual legal assistance guaranteed and investigations be focused, remains open.

\subsection{Immunities and Diplomatic Practice}

Immunities and the way such immunities are granted to suspects coming to Europe remain another challenge,

51 See Federal Public Prosecutor, press release of 11June 2013, available at www. generalbundesanwalt.de/de/showpress.php?themenid= 15 \&newsid $=477$.

52 See Federal Public Prosecutor, press release of 6 December 2012, available at www. generalbundesanwalt.de/de/showpress. php?themenid=14\&newsid=461. 
especially with regard to the powerful actors who mostly enjoy these immunities. There are a number of cases in which suspects of international crimes came to Germany with an official invitation issued by the German Government. With such an official invitation, the suspects enjoy immunity from prosecution according to article 20 of the Courts Constitution Act (Gerichtsverfassungsgesetz / GVG). This was the case in the visit of the Uzbek head of secret service Rustam Inoyatov in 2008, who was also allegedly involved in the Andijan massacre with hundreds of killed protesters and furthermore oversees systematic torture in Uzbek prisons; the Afghan member of cabinet Rashid Dostum, who is known as one of the most brutal Afghan warlords; and the Chief of General Staff of the Israeli Defense Forces Gabi Ashkenazi, involved in the Gaza war 2008/2009. The same applies to diplomatic visa issued by Germany, which provide for immunity under article 31 of the Vienna Convention on Diplomatic Relations. Thus, for example, Sri Lankan former major general and war crimes suspect Jagath Dias stayed in Germany as viceambassador. ${ }^{53}$ The practice by the Ministry of Foreign Affairs to invite or to issue diplomatic visa to suspects is opposed to Germany's obligations to prosecute international crimes under international conventions. The Ministry of Foreign Affairs is obliged to deny visa applications or requests for official visits in case the applicant or visitor was involved in the commission of an international crime. Decisive in a visa review application process is the law on the right of residence, which includes a provision establishing that the participation

53 It should be noted that Germany is by far not the only European state to which suspects of international crimes frequently travel. Sri Lankan and Bahraini suspects often visit the UK, Uzbek officials travel to meetings in Switzerland, the Colombian ambassador to Austria was allegedly involved in extrajudicial killings in the so called "falsos positivos" cases, and there are many more examples. in a criminal offense is a reason to deny the visa. ${ }^{54}$ This provision needs to be applied more carefully with regard to diplomatic personnel or invitations by the government. The current diplomatic practice, supported by existing laws widely granting immunities, is a major obstacle in prosecuting international crimes in Germany and Europe.

\section{Conclusion}

The example of Germany shows the development, challenges and shortcomings in prosecuting international crimes on the national level. While Germany moves in the right direction regarding its part in the international burden-sharing of investigations and prosecutions, many states still have to take the first step. The international criminal justice system introduced through the ICC Statute not only demands financial and political support for the ICC, but also makes changes necessary at the national level regarding legislation, prosecution policies and resources. Securing evidence present in a state's territory is an important first step and should be a goal for every European state. Thereupon, cases can be built and political pressure placed on many shoulders. Challenges remain, such as insufficient capacities, immunities or the lack of judicial review of politically motivated prosecutorial decisions. Nevertheless, in order to move forward from the prosecution of the politically light-weight cases to more powerful actors, states must begin and advance securing evidence in their territory and thus fulfill their part in the post-1998 system of international criminal justice.

54 See article 55 (2) 2 of the Residence Act (AufenthG).

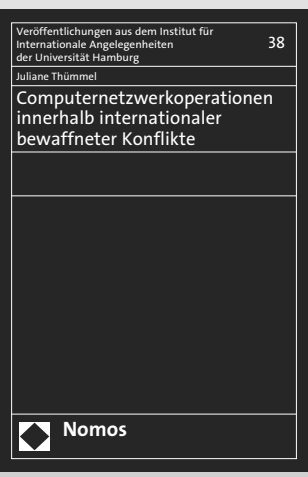

Computernetzwerkoperationen innerhalb internationaler bewaffneter Konflikte

Von Juliane Thümmel

2013, 273 S., brosch., 49,- $€$

ISBN 978-3-8329-7887-7

(Veröffentlichungen aus dem Institut für Internationale Angelegenheiten der Universität Hamburg, Bd. 38)
Die Integration von Informationstechnologie in alle Bereiche des privaten und öffentlichen Lebens beeinflusst nicht gesellschaftliche und wirtschaftliche Strukturen. Mit dem Cyberspace ist neben Land, See und Luftraum eine 4. Dimension in die Art und Weise der Konfliktaustragung getreten.

Das Werk stellt zunächst diese gesellschaftliche und sicherheitspolitische Entwicklung dar und gibt einen Überblick über die zurzeit wahrscheinlichsten Einsatzmöglichkeiten von Computernetzwerkoperationen unter Berücksichtigung realer Vorfälle. 